\title{
Financial Factors and Their Relative Importance Analysis in Peruvian Gold Mining Companies' Stock Price
}

\author{
Jose Fernando Vilcarromero Arbulú ${ }^{1}$, Jorge Luis Castilla Raimundo ${ }^{1}$, Pedro Bernabe Venegas Rodriguez ${ }^{1}$, Nivardo \\ Alonzo Santillán Zapata ${ }^{1} \&$ Jimmy Alberth Deza Quispe ${ }^{1}$ \\ ${ }^{1}$ Universidad Continental, Peru \\ Correspondence: Jose Fernando Vilcarromero Arbulú, Universidad Continental, Peru.
}

Received: September 7, 2020

Accepted: November 4, 2020

Online Published: January 14, 2021

doi:10.5430/ijfr.v12n2p251

URL: https://doi.org/10.5430/ijfr.v12n2p251

\begin{abstract}
The current research examined the relationship and relative importance of financial regressors on Peruvian gold mining companies' stock prices from 2009 to 2018. Chosen regressors were earnings per share, dividend per share and dividend yield. Fixed effects analysis was employed for regression analysis and $R^{2}$ decomposition for the relative importance study. Assumptions of stationarity, independence, no-multicollinearity, homoscedasticity and specification were fulfilled. Also, the values of Owen and Shapley were employed for decomposing $R^{2}$. It was found that earnings per share and dividend per share had a positive effect on the dependent variable; while dividend yield was found to be negatively related to stock price. Moreover, by the usage of $R^{2}$ decomposition it was noticed that the order of regressors importance was earnings per share, dividend per share and dividend yield. Then, it was stated that gold mining stock prices had a high dependence on profits and dividend payments in the analyzed period which can be related to the bearer's expectations.
\end{abstract}

Keywords: common shares, earnings per share, $\mathrm{R}^{2}$ decomposition, gold mining companies

\section{Introduction}

There are financial advisors who suggest investing in commodities as way to reduce risk in a portfolio and increase profits. Then, commodities can be classified as hard or soft ones. Hard commodities are natural resources extracted or mined; while soft commodities are related to goods from the agricultural sector (Shakil et al., 2018). From all commodities, gold is often seen as the least risky investment (Ahmed \& Vveinhardt, 2018). Furthermore, this commodity is employed as raw material for jewelry, coins, medals and electronic products (Fabozzi et al., 2008). Therefore, gold investors harness gold for defending themselves from inflation, financial crisis and other externalities (Shakil et al., 2018). However, commodity investing is not free of risk at all. Fabozzi et al. (2008) states that commodities have inherent volatility because of their dependence on international prices. Hence, an option for not receiving direct exposure to commodities volatility is to invest in commodity stocks; i.e. stock from mining or energy companies (Fabozzi et al., 2008).

Commodities stocks, as any other, are sold and bought in the stock market (Becket, 2017). In Peru, this market takes place in the Bolsa de Valores de Lima, hereinafter BLV, which is represented by the $S \& P / B V L$ Peru General Index. Here, mining companies stocks were responsible for almost $20.26 \%$ of the total number of operations in capital shares; also, they were responsible for $21.68 \%$ of total traded capital shares in the BVL last year (Bolsa de Valores de Lima, 2018).

It is also important to add the Peruvian mining tradition. Peruvian people have a millennial mining exploitation tradition (Lumbreras et al., 2008). For instance, the Incas, were well known for extracting gold and other precious metals (Petersen \& Brooks, 2010). In years of Spanish domination, the economic model was focused on extracting as much as possible precious metals, specially gold and silver, delivering them to Spain, thorough Callao and Sevilla ports (Chocano et al., 2010). When independence was reached, the economy was the main source of wealth of the young country (Cosamalón et al., 2011). Nowadays, due to world-wide industrial and technological development as long with globalization, metals became more attractive than ever. Peru, as a world class metal supplier, is the major producer of gold, zinc, lead and tin in Latin America; furthermore, the country is the world's second-largest supplier of copper, silver and zinc; and the sixth of gold (Ministerio de Energia y Minas, 2018). 
Gold exportations itself represents about $17.2 \%$ of total Peruvian trade exchange in FOB values (Ministerio de Energia y Minas, 2018). Moreover, such values have high perspectives of growing since there are actually almost 59 mining projects, seven related to gold, valued in more than 52 billon of dollars (Cámara de Comercio de Lima, 2019). Therefore, mining is the most important and attractive Peruvian investment sector. (Ernst and Young, 2019). Hence, specifically, Zevallos et al. (2017) claim that gold by itself is highly relevant for both Peruvian economy and Peruvian stock market. As stated before, for avoiding commodities volatility, investors could choose commodities stocks. Hence, in this exchange companies sell shares in which the buyer risks their money to obtain returns through dividends or the subsequent sale of their participation (Becket, 2017). Since there is no guarantee of the payment of dividends, shareholders may be moved to sell their participation in the stock market to get an immediate return (Milanez et al., 2019). Hence, investors should be aware of market prices of their shares. Fabozzi et al. (2008) claim that in commodities stocks, price is more highly influenced by commodity company financial performance than international prices.

In consequence, it is crucial to know and understand the importance of certain financial factors on stock price evolution. Moreover, the gold mining sector is crucial for the Peruvian economy, and its stock crucial for the stock market. Obviously, stock bearers' investors who seek continuously investment alternatives also should be aware of the determinants of the stock price of gold mining companies. Therefore, this research will be focused on analyzing financial performance indicators with the capability of influencing the market price of gold mining companies' shares indexed in the Lima Stock Exchange from 2009 to 2018 as well as each regressor relative importance by panel analysis and coefficient of determination decomposition, respectively.

\subsection{Literature Review}

Analysis of financial factors affecting stock price were carried in different productive sectors around the world. Yee \& Thaker (2018) analyzed the impacts of financial factors on the market share price of manufacturing companies indexed in the Malaysian stock market from 2011 to 2015. Along with other macroeconomic variables, the researchers employed as regressors earnings per share, dividend per share and return on equity [ROE]. It was found that both earnings per share and dividend per share had a positive effect on stock prices. Moreover, Ahmed (2018) researched the financial factors affecting the stock price of Pakistani textile firms from 2005 to 2014. The research showed a positive effect of both dividends per share and earnings per share on the firms's stock price.

Jeroh \& Edesiri (2015) studied the stock price determinants of Nigerian companies listed on the national Stock Exchange from 2001 to 2013. Then, the research found that dividend per share and net asset had a positive effect on the stock price. Furthermore, Sharif et al. (2015) aimed to identify the main determinants affecting the stock prices of companies listed in the Bahrein stock market from 2006 to 2010. The analysis found that ROE, book value per share, dividend per share and price earnings had positive effects on market share price, while dividend yield impacted negatively on the dependent variable. Also, Arslan \& Zaman (2014) aimed to research the impact of dividend yield and price earnings ratio on stock returns of non-financial firms of Pakistan. Then, data from Pakistani non-financial firms were collected belonging to the 1998-2009 period. The research found that there was a positive effect of price earnings on stock price; however, a negative relationship was found between dividend yield and stock price.

Furthermore, Garba (2014) studied the impact of dividend per share on stock returns of Nigerian manufacturing firms from 1991 to 2003. The research found that dividend per share had a positive major impact on stock price. Sarwar (2013) studied the effects of dividend's policy also Pakistani food and producer firms. The study employed data from 2006 to 2011 and showed that earnings per share and dividend per share had a positive relationship with stock prices.

Consequently, in different contexts researchers tried to identify factors with the capability of explaining stock prices, getting mixed results. However, it was not possible to find a previous research inquiring the relationship of financial factors on stock prices of Peruvian gold mining companies. Moreover, no previous research analyzed the relative importance of the regressors on the dependent variable. Therefore, it is necessary to analyze the financial factors affecting the stock price of gold mines as well as their relative importance.

\subsection{Theoretical Framework}

\subsubsection{Peruvian Stock Market}

The Peruvian stock market takes place in the $B V L$ and has been supervised since 2011 by the Superintendencia de Mercado y Seguros (Ley de Mercado de Valores, 2011). All companies indexed in the BVL must have an open access policy regarding their financial statements (Ley 29720, 2011). Moreover, the Ley General de Sociedades (1998), 
which is the ruling bill of any society in Peru, requests every company participating in the $B V L$ to be set up as an open society.

Moreover, the Peruvian law allows every society to have three kinds of shares: common shares, preference shares and investment shares. Although bearers of the three type of shares can participate in the dividends payment, they differ from each other in terms of political and preference rights. Since the current research will be focused on common stock, this kind of share will be explained in detail.

\subsubsection{Common Stock}

The Ley General de Sociedades (1998) stipulates that bearers of this kind of share have political rights over the entity as participation in the Shareholders' meetings; then, they can approve or disapprove the financial reports. Also, they can decide on the use of profits; hence, they can choose whether dividends are being paid or not. Moreover, they can elect and fire directors, request audits, select the audit entity, modify the business status, alienate assets, and participate in the decision of transforming, reorganizing, merging and even dissolving the company. They do not have any dividends payment preference in contrast of preferential shares; but they have plenty political rights in difference of investment shares bearers. The current research will analyze exclusively the common stock market price as the dependent variable.

\subsubsection{Financial Factors}

Financial factors describe the performance indicators of mining companies. By the usage of financial statements, the firm's performance can be systematically summarized. As stated before, by law every company listed in the $B V L$ must have their financial information openly available and audited by an independent specialized firm. Transparency regarding the financial information is crucial since current and potential investors are able to know the current status of the firm. Moreover, Adwan et al. (2020) claim that transparent enterprises have bigger chances of being durable across time. Therefore, it can be stated that data used in the current research is as much as exactly possible for the analysis. The regressors chosen for the analysis were earnings per share, dividend per share, and dividend yield due to the availability of data.

\subsection{Hypothesis}

In order to understand the effects and relative importance of financial factors on stock price evolution it is necessary to carry a panel data analysis as well as the coefficient of determination decomposition for understanding the pure effect of each regressor on the dependent variable. Then, the research will answer the following questions:

-How does earnings per share impacts on gold mining firms' stock price and what is its relative importance?

-What is the influence of dividend per share influences on gold mining firms' stock price and its relative importance?

-What is the relationship of dividend yield and gold mining firms stock price as well as its relative importance?

According to the literature review, it is expected that both earnings per share and dividend per share to have a positive effect on stock price; while dividend yields to has negative one. Hence expected hypothesis would be:

- $\quad$ H1: There is positive relationship of earnings per share and stock price.

- $\quad$ H2: There is a positive influence of dividend per share on stock price.

- H3: There is negative relationship of dividend yield and stock price.

No forecast can be done for the relative importance analysis since no previous study was found for such purpose.

\section{Method}

\subsection{Sample Size}

The current research employed a descriptive, quantitative, and longitudinal methodology to analyze financial factors relationship on gold mining companies' common stock market price from 2009 to 2018, and their relative importance. All statistical analysis employed STATA software. Data was gathered by examining firms' financial reports available in the Sociedad de Mercado y Valores (SMV) database. 
Table 1. Analyzed stock and variables

\begin{tabular}{lll}
\hline Analyzed stock & Dependent variable & Financial variables \\
\hline BUENAVC1 & Common stock price & Earnings per share \\
PODERC1 & & Dividend per share \\
\cline { 1 - 1 } MILPOC1 & Dividend yield \\
ATACOAC1 & \\
VOLCAAC1 & \\
\hline
\end{tabular}

Table 1 depicts analyzed stock as well as variables employed in the current study. The sample represents all the gold mining firms indexed in the Peruvian stock market.

\subsection{Chosen Regressors}

a) Earnings per share

Earnings per share are obtained by dividing after-tax profit and the number of shares issued by the entity (Sherman, 2015). Then, the dividend is the net income; while the divisor is composed of total company shares minus treasury shares [the company owned ones]. According to Jung et al. (2017), the coefficient can be harnessed as a predictive indicator; hence, earnings per share ratio can produce expectations and changes in the share price.

b) Dividend per share

According to Asadi (2013) this ratio is the coefficient between the total dividends paid and the number of issued shares. Although one precondition for dividend payment is the availability of funds expressed in the net income, not always dividends are paid since funds can be reinvested by the decision of the General Shareholders Meeting (Ley General de Sociedades, 1998). Also, common shares bearers, the analyzed one, do not have any preference in receiving dividends but they have the right to decide on its disposal (Ossio, 2004).

c) Dividend yield

This ratio provide the shareholders profit through dividends (Sherman, 2015). Dividend yield is obtained by dividing the dividend per share ratio by the stock price. According to Sherman (2015), it serves as a comparison tool between owned stock and other investment alternatives.

\subsection{Procedure}

The regression analysis was performed by the usage of panel data tools, specifically fixed effect regression. For variance decomposition it was necessary to employ Huttner and Sunder (2011) approach. It is important to add that static regression was harnessed because of the size of time $[\mathrm{T}]$ as well as the number of individuals $[\mathrm{N}]$ as suggested by Labra and Torrecillas (2018). Then, the regression model was:

$$
\text { Common_stock }_{\mathrm{it}}=\beta_{1} \mathrm{eps}_{\text {,it }}+\beta_{2} \mathrm{dps}_{\text {,it }}+\beta_{3} \text { divyield }_{\text {,it }}+\alpha_{\mathrm{i}}+\mu_{\mathrm{it}}
$$

Prior to regression and $R^{2}$ decomposition, it was necessary to reassure certain assumptions. First, chosen variables were evaluated to ensure the fulfilling of the assumption of stationary behavior as suggested by Baumöhl \& Lyócsa (2009).

Table 2. Stationary test

\begin{tabular}{lll}
\hline Variable & Statistic & p-value \\
\hline Stock price & 5.022 & 0.000 \\
\hline Earnings per share & 10.556 & 0.000 \\
\hline Dividend per share & 5.688 & 0.000 \\
\hline Dividend yield & 2.403 & 0.008 \\
\hline
\end{tabular}

Table 2 shows the stationary test results. Hadri's test was employed since the panel was balanced. As shown in Table 2 every selected variable was stationary at level. 
Then, it was necessary to accomplish the normal distribution condition as suggested by Fonti (2017). Therefore, data distribution was analyzed through the test proposed by Galvao et al (2013), which analyzes the asymmetry and kurtosis of sigma_u [between groups] and sigma_e [errors] residuals. Galvao's test analyzed them individually and jointly using the bootstrap technique suitable for panel-type data as it is exhibited in Table 3 (Alejo et al., 2015).

Table 3. Distribution test

\begin{tabular}{lllllllll}
\hline & Coefficient & Standard error & $\mathrm{z}$ & $\mathrm{p}>|\mathrm{z}|$ & Confidence Intervals 95\% & Joint test & $\mathrm{p}>\mathrm{chi}^{2}$ \\
\hline Model 1 & & & & & & & & \\
\hline Skewness_e & -56.576 & 49.378 & -1.150 & 0.252 & -153.355 & 40.203 & \multirow{2}{*}{5.5} & \multirow{2}{*}{0.0639} \\
\hline Kurtosis_e & 4143.661 & 2024.608 & 2.050 & 0.041 & 175.503 & 8111.820 & & \\
\hline Skewness_u & 97.658 & 51.513 & 1.900 & 0.058 & -3.306 & 198.622 & \multirow{2}{*}{4.10} & \multirow{2}{*}{0.1287} \\
\hline Kurtosis_u & 314.035 & 441.487 & 0.710 & 0.477 & -551.264 & 1179.334 & & \\
\hline
\end{tabular}

Table 3 shows that normality assumption is met since p value was higher than .05 then the null hypothesis of normal distribution could not be rejected.

Although according to theory fixed effects regression was the most suitable since all regressors were time-variant, to have statistical support modified Sargan-Hansen test, which is numerically equivalent to Hahn-Hausman test was carried since robust standard errors, for avoiding heteroskedasticity issues, was harnessed (Lee \& Okui, 2012). Therefore, there was both theoretical and statistical justification for using fixed effects regression as shown in Table 4.

Table 4. Sargan-Hansen test

\begin{tabular}{ll}
\hline Statistic & $\mathrm{p}$ value \\
\hline 27.526 & 0.000 \\
\hline
\end{tabular}

Table 4 depicts the Sargan-Hanses test results. It is noticed that the usage of fixed effects regression is favored since $\mathrm{p}<.05$

Moreover, specification of the model was evaluated through the Fourier Regression Specification Error - Test Sinusoidal transformation [Hereinafter, FRESETS] test, as depicted in Table 5, in order to avoid erroneous specifications because of omitted variables (DeBenedictis \& Giles, 1998).

Table 5. Specification test

\begin{tabular}{lll}
\hline Test & Value & $\mathrm{p}$ \\
\hline FRESETS 1 & 2.106 & 0.123 \\
\hline FRESETS 2 & 1.690 & 0.158 \\
\hline FRESETS 3 & 1.596 & 0.155 \\
\hline
\end{tabular}

Table 5 shows that FRESETS test revealed that the proposed model is correctly specified since its $\mathrm{p}$ value was higher than .05 .

Also, it was necessary to meet the assumptions of independence and non-multicollinearity. Hence Pesaran's test was employed to reassure that there was independence among the variables (Pesaran, 2004); and variation inflation factor analysis for avoiding multicollinearity issues. Both test results are depicted in Table 6 and 7. 
Table 6. Pesaran's test

\begin{tabular}{ll}
\hline Pesaran's test & $\mathrm{p}$ \\
\hline 0.404 & 0.267 \\
\hline
\end{tabular}

Table 6 reveals that Pesaran's test rejects the alternative hypothesis of dependence among the regressors since $\mathrm{p}>.05$

Table 7. Variation inflation factor

\begin{tabular}{lll}
\hline Variable & VIF & $1 / \mathrm{VIF}$ \\
\hline Earnings per share & 1.22 & 0.822 \\
\hline Dividend per share & 1.76 & 0.569 \\
\hline Dividend yield & 1.49 & 0.669 \\
\hline Mean VIF & 1.57 & \\
\hline
\end{tabular}

Table 7 indicates that VIF analysis outcome does not provide evidence of multicollinearity since the mean values were not higher than 10 .

As stated before, robust standard errors values were employed as suggested by Stock \& Watson (2008) in the regression results. Furthermore, as an approach to get the weight of each regressor, standardized coefficients were also harnessed. Finally, relative importance analysis was performed by decomposing the coefficient of determination, $R^{2}$, of every regressor as suggested by Huettner \& Sunder (2011). Moreover, by multiplying individual and $\mathrm{R}^{2}$, and overall $R^{2}$ it was possible to get the direct effect of each variable on the dependent variable.

\section{Results}

\subsection{Descriptive Statistics}

Table 8. Financial factors descriptive statistics

\begin{tabular}{|c|c|c|c|c|c|c|c|c|c|c|c|}
\hline \multirow[t]{2}{*}{ Variable } & \multirow[t]{2}{*}{ Measure } & \multicolumn{10}{|l|}{ Year } \\
\hline & & 2009 & 2010 & 2011 & 2012 & 2013 & 2014 & 2015 & 2016 & 2017 & 2018 \\
\hline \multirow{5}{*}{$\begin{array}{l}\text { V. stock } \\
\text { price }\end{array}$} & Mean & 8.636 & 11.035 & 8.696 & 8.101 & 2.702 & 2.565 & 1.158 & 2.765 & 3.912 & 4.131 \\
\hline & Median & 2.700 & 1.745 & 1.670 & 1.491 & 0.752 & 0.820 & 0.470 & 1.010 & 1.420 & 1.250 \\
\hline & Max & 33.340 & 48.430 & 37.780 & 36.060 & 10.740 & 10.580 & 4.212 & 10.254 & 13.897 & 15.938 \\
\hline & Min & 0.796 & 0.687 & 0.301 & 0.149 & 0.075 & 0.094 & 0.084 & 0.140 & 0.225 & 0.238 \\
\hline & $\begin{array}{l}\text { Coefficient } \\
\text { of } \\
\text { variation }\end{array}$ & 13.892 & 20.917 & 16.282 & 15.641 & 4.511 & 4.490 & 1.722 & 4.247 & 5.656 & 6.637 \\
\hline \multirow{5}{*}{$\begin{array}{l}\text { Earnings } \\
\text { per share }\end{array}$} & Mean & 0.525 & 0.611 & 0.404 & 0.584 & -0.021 & -0.015 & -0.224 & -0.161 & 0.172 & 0.074 \\
\hline & Median & 0.086 & 0.116 & 0.120 & 0.074 & 0.059 & 0.049 & -0.024 & 0.030 & 0.162 & 0.003 \\
\hline & Max & 2.333 & 2.605 & 1.529 & 2.544 & 0.147 & 0.097 & 0.202 & 0.351 & 0.417 & 0.322 \\
\hline & Min & -0.022 & 0.024 & 0.014 & -0.009 & -0.422 & -0.299 & -1.248 & -1.274 & 0.011 & -0.053 \\
\hline & $\begin{array}{l}\text { Standard } \\
\text { deviation }\end{array}$ & 1.013 & 1.117 & 0.634 & 1.102 & 0.233 & 0.164 & 0.583 & 0.637 & 0.166 & 0.149 \\
\hline \multirow{3}{*}{$\begin{array}{l}\text { Dividend } \\
\text { per share }\end{array}$} & Mean & 0.051 & 0.115 & 0.147 & 0.154 & 0.108 & 0.028 & 0.014 & 0.028 & 0.108 & 0.046 \\
\hline & Median & 0.013 & 0.031 & 0.051 & 0.030 & 0.030 & 0.025 & 0.004 & 0.013 & 0.087 & 0.004 \\
\hline & Max & 0.160 & 0.460 & 0.560 & 0.600 & 0.336 & 0.070 & 0.047 & 0.093 & 0.263 & 0.136 \\
\hline
\end{tabular}




\begin{tabular}{|c|c|c|c|c|c|c|c|c|c|c|c|}
\hline & Min & 0.000 & 0.000 & 0.000 & 0.000 & 0.000 & 0.000 & 0.000 & 0.000 & 0.000 & 0.000 \\
\hline & $\begin{array}{l}\text { Coefficient } \\
\text { of } \\
\text { variation }\end{array}$ & 1.374 & 1.696 & 1.587 & 1.656 & 1.317 & 0.945 & 1.398 & 1.355 & 1.052 & 1.374 \\
\hline \multirow{5}{*}{$\begin{array}{l}\text { Dividend } \\
\text { yield }\end{array}$} & Mean & 0.012 & 0.015 & 0.024 & 0.026 & 0.045 & 0.031 & 0.025 & 0.014 & 0.053 & 0.014 \\
\hline & Median & 0.003 & 0.009 & 0.025 & 0.017 & 0.031 & 0.015 & 0.013 & 0.010 & 0.007 & 0.004 \\
\hline & Max & 0.052 & 0.046 & 0.050 & 0.089 & 0.135 & 0.086 & 0.067 & 0.046 & 0.185 & 0.062 \\
\hline & Min & 0.000 & 0.000 & 0.000 & 0.000 & 0.000 & 0.000 & 0.000 & 0.000 & 0.000 & 0.000 \\
\hline & $\begin{array}{l}\text { Coefficient } \\
\text { of } \\
\text { variation }\end{array}$ & 1.893 & 1.185 & 0.771 & 1.396 & 1.160 & 1.189 & 1.189 & 1.288 & 1.494 & 1.864 \\
\hline
\end{tabular}

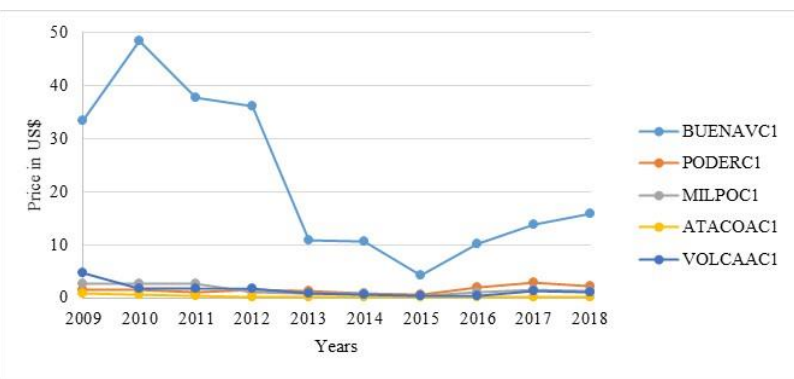

Figure 1. Common stock market price

Figure 1 shows the values of the stock prices of each gold mining company from 2009 to 2018. It can be seen that in all the periods BUENAVCl had the most expensive value. However, the distance towards the other shares was almost erased in 2015. From 2015 to 2018 the distance towards the other shares increased, but it did not reach its initial levels.

Moreover, according to Figure 1 PODERCI can be pointed as the only share that was able to surpass its initial levels. On the other hand, VOLCAACI and MILPOCI suffered reductions in their market values in the whole period. In the case of ATACOACl its market price did not vary a lot from the initial period to 2018.

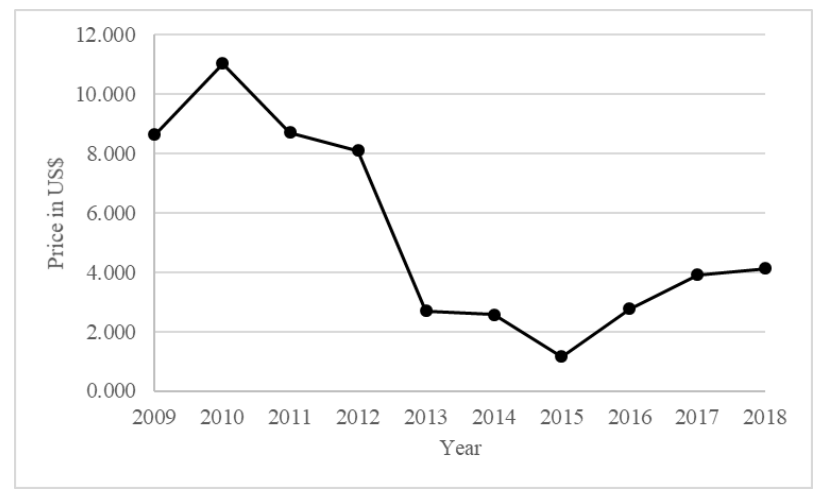

Figure 2. Common stock market price average values

Both Table 8 and Figure 2 provide the behavior on average of the stock prices of gold mining companies. It can be seen that a peak was reached in 2010; while its lowest value happened in 2015. From 2010 to 2015, average stock prices fell; however, from 2015 to 2018 they grew. The highest price reached by a company was 48.430 dollars per share; while the lowest value was 0.075 dollars per share as depicted in Table 8. 


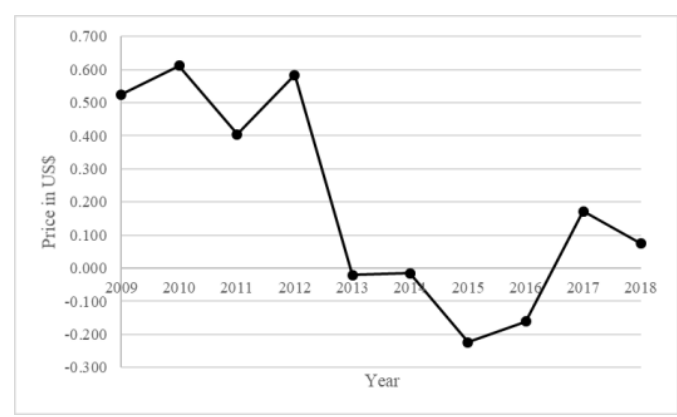

Figure 3. Earnings per share average values

Figure 3 and Table 8 portray those earnings per share average values had a big fall from 2012 to 2015. Moreover, in the period 2014-2016 the average value were negative ones. A little recover happened in 2017 but it fell again in 2018. As also depicted in Table 8, in 2010 and 2012 earnings per share had peak values, while in the 2015-2016 period it reached its lowest value ever.

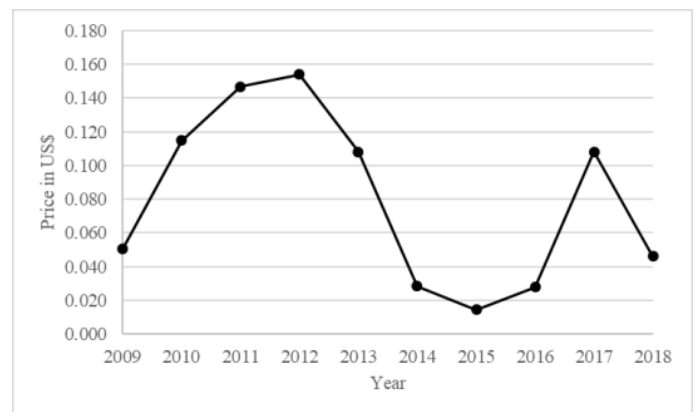

Figure 4. Dividend per share average values

For dividend per share, both Table 8 and Figure 4 depict a high volatile scenario in its average values. Two periods of continuous growing periods are shown. One from 2009 to 2012 and the other from 2015 to 2017. In that way, the "worst" year happened in 2015 when the average values reached their lowest value. Similar to earnings per share, the highest value was achieved in 2012. Table 8 shows that in the whole period there was at least one company that did not pay dividends to their shareholders.

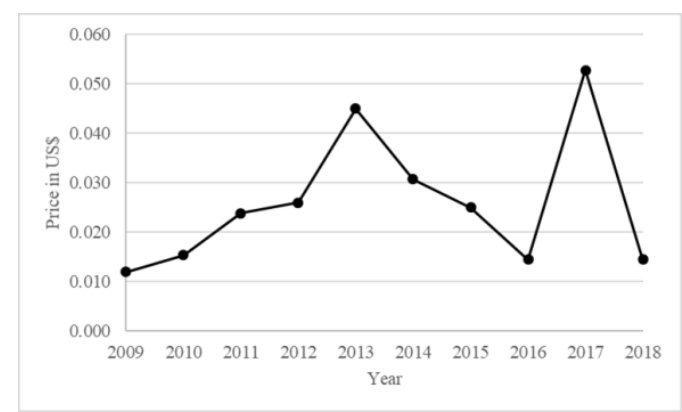

Figure 5. Dividend yield average values

Table 8 and Figure 5 shows that Dividend yield average values had a growing interval from 2009 to 2013. However, a decreasing period was followed until 2016. In 2017, the highest dividend yield average value was reached. When 
comparing 2018 value and 2009 one it can be seen that the last year average value was little bit higher than the one of the initial year.

\subsection{Regression and Relative Importance Analysis}

Table 9. Regression analysis

\begin{tabular}{lllllll}
\hline Common stock & Coefficient & Robust Standard Error & T & P>t & Confidence Intervals 95\% \\
\hline Earnings per share*** & 7.684 & 0.420 & 18.290 & 0.000 & 6.716 & 8.653 \\
\hline Dividend per share*** & 3.693 & 1.029 & 3.590 & 0.007 & 1.321 & 6.066 \\
\hline Dividend yield ${ }^{*}$ & -53.502 & 25.155 & -2.130 & 0.066 & -111.509 & 4.505 \\
\hline Constant & 5.395 & 0.705 & 7.650 & 0.000 & 3.770 & 7.021 \\
\hline F & 122.810 & & 0.000 & & \\
\hline sigma_u & 5.831 & & & & & \\
\hline sigma_e & 4.531 & & & & & \\
\hline rho & 0.624 & & & & & \\
\hline
\end{tabular}

*** significant at $1 \%$

** significant at $10 \%$

Table 10. Regression analysis with standardized coefficients

\begin{tabular}{llllllc}
\hline Common stock & Coefficient & Robust Standard Error & T & P>t & Confidence Intervals 95\% \\
\hline Earnings per share*** & 0.536 & 0.029 & 18.290 & 0.000 & 0.468 & 0.603 \\
\hline Dividend per share*** & 0.145 & 0.041 & 3.590 & 0.007 & 0.052 & 0.239 \\
\hline Dividend yield* & -0.230 & 0.108 & -2.130 & 0.066 & -0.479 & 0.019 \\
\hline Constant & $-1.61 \mathrm{E}-09$ & $1.05 \mathrm{E}-09$ & -1.530 & 0.164 & $-4.02 \mathrm{E}-09$ & $8.10 \mathrm{E}-10$ \\
\hline F & 122.810 & & 0.000 & & \\
\hline sigma_u & 0.491 & & & & & \\
\hline sigma_e & 0.382 & 0.624 & & & & \\
\hline rho & & & & & & \\
\hline
\end{tabular}

*** significant at $1 \%$

** significant at $10 \%$

Table 11. Decomposition analysis

\begin{tabular}{llll}
\hline Common stock & Overall R2 \% & Individual \% & Individual R2 \% \\
\hline Earnings per share & & 79.948 & 69.411 \\
\hline Dividend per share & 86.820 & 11.753 & 10.204 \\
\hline Dividend yield & & 8.299 & 7.205 \\
\hline
\end{tabular}

Table 9 and Table 10 exhibit that earnings per share and dividend per share had a positive effect on stock price, while there was a negative relationship of dividend yield and stock price. According to standardized coefficients, earnings per share are the most important regressor as portrayed in Table 10.

According to Table 11, the coefficient of determination $\left[R^{2}\right]$ for the whole model was .868 , then the regressors were able to explain $86.82 \%$ of the dependent variable effects. When decomposing $R^{2}$, it can be seen that, $79.948 \%$-the 
highest one- of the overall value was attributed to earnings per share; while the lowest contribution belonged to firm's size [8.299\%]. In the case of dividend per share, it contributed $11.753 \%$ to the overall $R^{2}$.

Moreover, by multiplying individual $\%$ by overall $R^{2}$, Table 11 portrays that earnings per share by itself was able to explain $79.948 \%$ of the dependent variable effects, dividend per share was responsible of $10.204 \%$, and dividend yield explained $7.205 \%$.

Consequently, statistical significance, standardized coefficients, and decomposition analysis gave strong evidence for claiming that the most important variable for explaining gold mining companies' common stock market price from 2009 to 2018 was earnings per share.

Finally, the obtained $\mathrm{F}$ value in Table 9 and Table 10 was about 122.810, with a p-value of .0000 ; hence, it was possible to claim the model was acceptable as all coefficients were different from zero.

In consequence, the equation 1 should be stated as follows:

Common_stock $_{\mathrm{it}}=5.395+7.684 \mathrm{eps}_{, \mathrm{i}(2009-2014)}+3.893 \mathrm{dps}_{\mathrm{i}_{(2009-2014)}}-53.502$ divyield $_{\mathrm{i}(2009-2014)}+\alpha_{(2009-2014)}+\mu_{\mathrm{i}(2009-2014)}$

Then, there is evidence to claim that both earnings per share and dividend per share had a positive effect on the stock price; while, dividend yield had a negative one; which were the expected results as stated in the introductory apart. Hence, hypothesis $\mathrm{H} 1, \mathrm{H} 2$, and $\mathrm{H} 3$ are accepted since the $\mathrm{p}$ values were lower than .05 giving significance in the relationships observed.

\section{Discussion}

The research main finding is that earnings per share had a positive and significant relationship to gold mining stock prices. Moreover, according to standardized coefficient and decomposition analysis, earnings per share was the most important regressor at explaining the dependent variable. The discussion will be centered in the regression results since no previous literature was found for relative importance analysis. Regression result is similar to the findings of Yee \& Thaker (2018), in their research in the textile sector. Also, that finding was encountered by Ahmed (2018) in their study in the textile sector. Moreover, Sharif et al. (2015) detected a related relationship in the Bahrein companies. Finally, Sarwar (2013) in their study of food production also found a positive relationship of earnings per share and stock price

Moreover, the positive relationship of dividend per share and stock price is similar to the findings of Yee \& Thaker (2018), Ahmed (2018), Jeroh \& Edesiri (2015), Sharif et al. (2015), Garba (2014), and Sarwar (2013). The aforementioned studies in their respective economic sectors also found that dividend per share had a positive impact on the studied firms' stock prices such as Jeroh \& Edesiri (2015) and Garba (2014) in the Nigerian companies.

Finally, the negative relationship of dividend yield and stock price was also found in the Sharif et al. (2015) research in the Bahrain stock market and Arslan \& Zaman (2014) study in nonfinancial firms. Although none of the them study commodity stocks specifically, it is interesting to note that results regarding dividend yield is similar no matter the sector.

\section{Conclusions}

The current research main objective was to identify which regressors explained the best gold mining companies' common stock market prices from 2009 to 2018. Hence, regressors such earnings per share, dividend per share, and dividend yield were chosen as potential explanatory factors. After statistical analysis, it was found that earnings per share and dividend per share had a positive effect on the dependent variable; while dividend yield was negatively related to stock prices. Also, additional tests gave evidence to claim that earnings per share were the most important regressor for explaining gold mining companies' stock price.

Since earnings per share are the coefficient of net income and issued shares; it can be claimed that current and potential investors look after the financial performance of mining firms, specially the profits. Then it generates expectations that affect the stock prices. Although variations of earnings per share can also be linked to changes in the number of issued shares, from 2009 to 2018 such changes were not as frequent as net income changes.

As stated before, common stock bearers do not have any preference treatment on being paid dividends; but they have plenty of political rights. Then, although they do not have a secured right to get dividends, they look after the stock that pays dividend off. Hence, the expectative of earning dividends seem to boost the stock price in gold mining companies. Both earnings per share and dividend per share were found to be the most important financial factors for stock price, then potential and current investors should be centered in those ratios.

Finally, dividend yield seemed to be negative related to stock price. A possible explanation would be that companies may be more moved to pay off dividends to shareholders as a compensation for the falling of the stock price. On the 
other hand, it also can be the fact that companies do not see as favorable to change negatively the dividends politics in stock price falling periods, then they just maintain the current dividend policy.

\section{Recommendation}

The current research analyzed the impact of selected financial factors on the stock price of gold mining companies listed in the Peruvian stock market. Consequently, based on the results, gold mining companies should favorable dividend politics to the shareholders and avoid losses as much as possible since both factors seemed to have a direct relationship on stock price. Moreover, it would be recommendable for further investigations to include non-financial variables such as corporate governance, social responsibility or working environment and explore if they have any effect on stock price. Finally, including in the analysis gold mining firms of other countries and compare them with the Peruvian ones also may be advisable.

\section{References}

Adwan, S., Alhaj-Ismail, A., \& Claudia, G. (2020). Fair value accounting and value relevance of equity book value and net income for European financial firms during the crisis. Journal of International Accounting, Auditing and Taxation, 39(2020). https://doi.org/10.1016/j.intaccaudtax.2020.100320

Ahmed, I. (2018). Impact of dividend per share and earnings per share on stock prices: A case study from Pakistan (Textile Sector). IJSSHE-International Journal of Social Sciences, Humanities and Education Volume, 2(2), 1-10.

Ahmed, R. R., \& Vveinhardt, J. (2018). Estimation of causal relationship between world gold prices and KSE 100 index: Evidence from Johansen cointegration technique. Acta Economica, 68(1), 51-77. https://doi.org/10.1556/032.2018.68.1.3

Alejo, J., Galvao, A., Montes-rojas, G., \& Sosa-Escudero, W. (2015). Tests for normality in linear panel data models. In Centro de Estudios Distribuitivos, Laborales y Sociales.

Arslan, M., \& Zaman, R. (2014). Impact of dividend yield and price earnings ratio on stock returns: A study non-financial listed firms of Pakistan. Research Journal of Finance and Accounting, 5(19), 2222-2847.

Asadi, A. (2013). Examining the relationship between the dividend policy and stock prices in companies listed on tehran stock exchange. Research Journal of Applied Sciences, Engineering and Technology, 6(22), 4186-4191. https://doi.org/10.19026/rjaset.6.3530

Baumöhl, E., \& Lyócsa, S. (2009). Stationarity of time series and the problem of spurious regression. MPRA. Retrieved from https://mpra.ub.uni-muenchen.de/27926/

Becket, M. (2017). How the stock market works: a beginner's guide to investment (6th ed.). Kogan Page Ltd. Retrieved from http://search.ebscohost.com/login.aspx?direct=true\&db=nlebk\&AN=1528089\&site=eds-live

Bolsa de Valores de Lima. (2018). Informe Bursatil. Retrieved from https://www.bvl.com.pe/pubdif/infmen/Ultimo_IB.pdf

Cámara de Comercio de Lima. (2019). Informe ecoómico. La Cámara, 7-8.

Chocano, M., Contreras, C., Quiroz, F., Mazzco, C., \& Flores, R. (2010). Compendio de Historia Económica del Perú III. In Compendio de Historia Económica del Perú III. https://doi.org/10.1007/s13398-014-0173-7.2

Cosamalón, J., Armas, F., Deustua, J., Monsalve, M., \& Salinas, A. (2011). Compendio de Historia Económica del Perú IV: Economía de la primera centuria independiente. In Compendio de Historia Económica del Perú (1st ed.). Banco Central de Reserva del Peru.

DeBenedictis, L., \& Giles, D. (1998). Robust specification testing in regression: the FRESET test and autocorrelated disturbances. Journal of Quantitative Economics, 15(1), 67-76.

Ernst and Young. (2019). Peru's mining \& metals investment guide 2019/2020. Retrieved from http://www.embajadadelperu.org.co/docs/Mining2019-2020.pdf

Fabozzi, F., Fuss, R., \& Kaise, D. (2008). The handbook of commodity investing (1st ed.). John Wiley \& Sons, Ltd.

Fonti, V. (2017). Feature Selection using LASSO. VU Amsterdam, 1-26. https://doi.org/10.1109/ACCESS.2017.2696365

Galvao, A., Montes-rojas, G., Sosa-Escudero, W., \& Wang, L. (2013). Tests for skewness and kurtosis in the one-way error component model. Journal of Multivariate Analysis, 122, 35-52.

Garba, A. (2014). Impact of dividend- per- share on common stock returns: a case study of some selected manufacturing firms listed on the Nigerian stock exchange. European Journal of Business and Management, 6(30), 36-43. 
Huettner, F., \& Sunder, M. (2011). Working Paper, No. 100 Frank Hüttner / Marco Sunder Decomposing R2 with the Owen value Oktober 2011 Decomposing with the Owen value. In Working Paper (Issue 100). Retrieved from http://www.marco-sunder.de/stata/rego.html

Jeroh, E., \& Edesiri, G. O. (2015). An empirical analysis of share price determinants in Nigeria: A dividend and net asset replica. Scientific Papers of the University of Pardubice, Series D: Faculty of Economics and Administration, 22(33), 46-54.

Jung, M. J., Keeley, J. H., \& Ronen, J. (2017). The Predictability of Analyst Forecast Revisions. Journal of Accounting, Auditing \& Finance, 34(3), 434-457.

Labra, R., \& Torrecillas, C. (2018). Estimando datos de panel dinámicos. Un enfoque práctico para abordar paneles largos. Revista Colombiana de Estadistica, 41(1), 31-52. https://doi.org/10.15446/rce.v41n1.61885

Lee, Y., \& Okui, R. (2012, May). Hahn-Hausman Test as a Specification Test. SSRN Electronic Journal. https://doi.org/10.2139/ssrn.1759077

Ley de Mercado de Valores. (2011). Testimony of Congreso de la República del Perú.

Ley General de Sociedades. (1998). Testimony of Congreso de la República del Perú. Ley 29720, 28. Diario Oficial El Peruano 445296 (2011).

Lumbreras, L., Kaulicke, P., Santillana, J. I., \& Espinoza, W. (2008). Compendio de historia económica del Perú I:Economía prehispánica (1st ed.). Banco Central de Reserva del Peru.

Milanez, B., Mansur, M. S., \& Wanderley, L. J. de M. (2019). Financeirização E O Mercado De Commodities: Uma Avaliação a Partir Do Setor De Mineral. Revista Tamoios, 15(1), 104-125. https://doi.org/10.12957/tamoios.2019.38676

Ministerio de Energia y Minas. (2018). Anuario Minero 2018. https://doi.org/10.30875/ee10314e-es

Ossio, J. (2004). Dividendo preferencial de las acciones sin derecho a voto. Iust et Veritas, 14(28), 68-75. Retrieved from http://revistas.pucp.edu.pe/index.php/iusetveritas/article/view/16047

Pesaran, M. H. (2004). General Diagnostic Tests for Cross Section Dependence in Panels. Iza, 1240, 1-42. Retrieved from http://www.dspace.cam.ac.uk/handle/1810/446

Petersen, G., \& Brooks, W. E. (2010). Mining and metallurgy in ancient Perú. Special Paper of the Geological Society of America. https://doi.org/10.1130/2010.2467

Sarwar, M. S. (2013). Effect of dividend policy on share holder's wealth: A study of IT and banking industry in India. Global Journal of Management and Business Research, 13(7), 47-54. Retrieved from http://creativecommons.org/licenses/by-nc/3.0/

Shakil, M. H., Mustapha, I. M., Tasnia, M., \& Saiti, B. (2018). Is gold a hedge or a safe haven? An application of ARDL approach. Journal of Economics, Finance and Administrative Science, 23(44), 60-76. https://doi.org/10.1108/JEFAS-03-2017-0052

Sharif, T., Purohit, H., \& Pillai, R. (2015). Analysis of factors affecting share prices: the case of bahrain stock exchange. International Journal of Economics and Finance, 7(3), 207-216. https://doi.org/10.5539/ijef.v7n3p207

Sherman, E. (2015). A manager's guide to financial analysis (6th ed.). American Management Association.

Stock, J. H., \& Watson, M. W. (2008). Heteroskedasticity-robust standard errors for fixed effects panel data regression. Econometrica, 76(1), 155-174. https://doi.org/10.1111/j.0012-9682.2008.00821.x

Yee, E. C. P., \& Thaker, H. M. T. (2018). Determinants of share price fluctuation: evidence from the manufacturing industry in Malasya. Skyline Business Journal, 14(1), 58-70.

Zevallos, M., Villarreal, F., Del Carpio, C., \& Abbara, O. (2017). Metal Prices and International Market Risk in the Peruvian Stock Market. Revista Economia, 40(79), 87-104. https://doi.org/10.18800/economia.201701.003

\section{Copyrights}

Copyright for this article is retained by the author(s), with first publication rights granted to the journal.

This is an open-access article distributed under the terms and conditions of the Creative Commons Attribution license (http://creativecommons.org/licenses/by/4.0/). 